\title{
MANAGING DESIGN AND CONSTRUCTION DATA ON THE ADVANCED NEUTRON SOURCE PROJECT INFORMATION NETWORK'
}

\author{
J. E. Cleaves \\ Oak Ridge National Laboratory \\ P.O. Box 2009 \\ Oak Ridge, Tennessee 37831-8218 \\ To be presented at the \\ 9th Power Plant Dynamics, \\ Control, and Testing Symposium \\ Knoxville, Tennessee \\ May 24-26, 1995
"The submitted manuscript has been authored by a contractor of the
U.S. Government under contract DE-AC05-81OR21400.
Accordingty, the U.S. Govermment retains a nonexclusive, royalty-free license to publish or reproduce the published form of this contribution, ar allow others to do so, for U.S. Government purposes."

\section{DISTRIBUTION OF THIS DOCUMENT IS UNLIMITED}

Research sponsored by the Office of Energy Research, U.S. Department of Energy, under contract DE-AC05-840R21400 with Martin Marietta Energy Systems, Inc.

\section{DISCLAIMER}

This report was prepared as an account of work sponsored by an agency of the United States Government. Neither the United States Government nor any agency thereof, nor any of their employees, makes any warranty, express or implied, or assumes any legal liability or responsibility for the accuracy, completeness, or usefulness of any information, apparatus, product, or process disclosed, or represents that its use would not infringe privately owned rights. Reference herein to any specific commercial product, process, or service by trade name, trademark, manufacturer, or otherwise does not necessarily constitute or imply its endorsement, recommendation, or favoring by the United States Government or any agency thereof. The views and opinions of authors expressed herein do not necessarily state or reflect those of the United States Government or any agency thereof. 


\section{MANAGING DESIGN AND CONSTRUCTION DATA ON THE ADVANCED NEUTRON SOURCE PROJECT INFORMATION NETWORK}

The Advanced Neutron Source (ANS) is a new $\$ 2.9$ billion research facility proposed for construction on the U.S. Department of Energy reservation near Oak Ridge National Laboratory. Its 330-MW heavy water reactor will be used to provide steady-state beams of neutrons for experiments by more than 1000 researchers per year in the fields of materials science and engineering, biology, chemistry, and materials analysis. The facility will also provide irradiation capabilities for the production of radioisotopes for medical applications, research, industry, and materials testing.

The documentation needed to support the design, construction, and operation of ANS is expected to be similar to that needed for a nuclear power plant. If current practices are continued, this will result in the generation and management of more than 100 million pages of paper during the 10-year design and construction phase of the project. Storage of this information as paper would require constructing a building, in addition to the labor costs associated with handling paper. Thus, there is a great incentive to handle information electronically.

This paper describes the project information network (PDN) that will connect the industry team (architect/engineer, reactor manufacturer, construction manager and other subcontractors) and other project participants so that data can be shared and integrated. This network will be a key element in creating the tens of thousands of construction drawings, specifications, instructions, procedures, and other documents needed to support design, construction, and startup.

This design, construction, and startup effort will include operations and maintenance personnel and will generate all operations and maintenance procedures, training materials, instructions, manuals, and other materials needed for operations at startup. Therefore, by storing the data in electronic forms that are readily usable by operations, maintenance, and facility business computing system applications, the PIN will greatly simplify the traditionally expensive turnover activity of preparing data for operational use. 
Thus the main purposes of the PIN are the following:

1. to support efficient production, generation, review, and approval of design and construction data by the project team; and

2. to automate the turnover of this information to operations and maintenance personnel who will operate the plant.

The purpose of this PIN is not to replace the human functions of analyzing, calculating, or otherwise manipulating data to produce technical output. The PIN is only to provide ready access to data, software, and other tools needed by users to perform these functions.

Research performed for the Electric Power Research Institute (EPRI 1987) and recent experience in using three-dimensional computer models and other computer-aided engineering techniques (Brake 1990; Warren 1994) show potential savings of tens of millions of dollars. Analyses performed for ANS indicate that a $\$ 5$ million investment in the PIN could produce a $\$ 60$ million return.

The PIN architecture includes software applications and services that users access via a graphical user interface. They use these services to create and process documents, calculations, data, and other working files. When ready, these working files are officially transmitted to the project via an electronic transmittal function that is incorporated into appropriate network systems. The transmittal function collects all data pertinent to the document and/or information and inputs it to appropriate databases so that it can be tracked, and inputs requested user actions to the network action commitment tracking system. The action commitment tracking system tracks all user commitments and displays them on a window included in the graphical user interface.

A document management system, master equipment data base, and other appropriate systems will also be provided to manage the transmitted files.

T. E. Brake, "Network Communications at the Diablo Canyon Power Plant Integrating Plant Process Data," p. 311 in Transactions American Nuclear Society Anmual Meeting, Vol. 61, June 10-14, 1990.

EPRI, Guidelines for Specifying Integrated Computer-Aided Engineering Applications for Electric Power Plants, EPRI Report NP-5159S, Electric Power Research Institute, Palo Alto, Calif., May 1987.

J. E. Warren, Gilbert/Commonwealth, Inc., personal communication to J. E. Cleaves, Martin Marietta Energy Systems, Inc., Oak Ridge National Laboratory, March 1994. 